\title{
PCR based analysis of Haemobartonellosis (Candidatus mycoplasma haematoparvum and Mycoplacma haemocanis) and its prevalence in dogs in Isfahan, Iran
}

\author{
Sayed Reza Hosseini, ${ }^{1}$ Arman Sekhavatmandi ${ }^{2}$ and Faham Khamesipour ${ }^{3,4}$ \\ ${ }^{1}$ Department of Pathobiology, Faculty of Veterinary Medicine, Shahrekord Branch, Islamic Azad University, \\ Shahrekord, Iran \\ ${ }^{2}$ Graduated of Veterinary Medicine, Shahrekord Branch, Islamic Azad University, Shahrekord, Iran \\ ${ }^{3}$ Cellular and Molecular Research Center, Sabzevar University of Medical Sciences, Sabzevar, Iran \\ ${ }^{4}$ Department of Pathobiology, School of Veterinary Medicine, Shiraz University, Shiraz, Iran
}

\section{ABSTRACT}

The present study was conducted to determine prevalence of Candidatus mycoplasma haematoparvum and Mycoplacma haemocanis in dogs in Isfahan (Central province of Iran). Total 294 dogs were the materials of the study. To determine molecular and haematological parameters, $2 \mathrm{ml}$ blood with and without anticoagulant were taken according to technique from vena cephalica antebrachii. Candidatus mycoplasma haematoparvum and Mycoplacma haemocanis was detected in blood smears preparations of $26(8.82 \%)$ by Geimsa staining and (20.06\%) by PCR. Based on the $16 \mathrm{~S}$ rDNA sequence, a specific PCR assay was developed.

KEY WORDS: HAEMOBARTONELLOSIS, DOGS, IRAN, PCR

\section{INTRODUCTION}

The organisms formerly known as Haemobartonella and Eperythrozoon spp. are small, pleomorphic bacteria that parasitize red blood cells of a wide range of vertebrate animals. Haemobartonellosis, infectious anaemia of dogs is caused by Candidatus mycoplasma haematopar-

\section{ARTICLE INFORMATION:}

*Corresponding Author: borji_milad@yahoo.com Received 21 $1^{\text {st }}$ March, 2017

Accepted after revision $21^{\text {st }}$ June, 2017

BBRC Print ISSN: 0974-6455

Online ISSN: 2321-4007 CODEN: USA BBRCBA

. Thomson Reuters ISI ESC and Crossref Indexed Journal

. NAAS Journal Score 2017: 4.31 Cosmos IF : 4.006

- A Society of Science and Nature Publication, 2017. All rights reserved.

Online Contents Available at: http//www.bbrc.in/ vum and Mycoplacma haemocanis, an anaplasma species belonging to the rickettsia family. The infection is characterized by extreme fatigue, depression, anorexia, weight loss and anaemia and may cause death (Lumb, 2001; Neimark et al., 2001; Torkan et al., 2014).

The pathogen can be identified as small coccoids, rings or strings on erythrocyte membrane or free in 
plasma in Giemsa staining of blood smears (Murray et al., 1995; Lumb, 2001).Mode of transmission has not been clearly identified but bloodsucking arthropods like ticks were the suspected vectors. Another possible mode of transmission is close fighting among dogs. Intrauterine and lactation-related transmission was also reported (Neimark et al., 2002; Jane et al., 2005).Acute disease presents with fever, anorexia, weight loss, jaundice, apathy, adenopathy, motor incoordination and splenomegaly (North, 1978; Sykes et al., 2004). Chronic disease has atypical symptoms like anaemia, weight loss, paraplegia, dehydration, hyperesthesia and depression (Saykes et al., 2008). Latent form of the infection has also been described (Pitulle et al., 1999).Diagnosis of haemobartonellosis depends on clinical and hematological findings together with microscopic examination of blood smears and specific serological and PCR testing for the pathogen (Lappin et al., 2006). Various antibiotics were reported to be effective in the treatment of haemobartonellosis. Haemobartonellosis was first described in 1953 in the United States (Splitter et al., 1956) but the number of studies about incidence and prevalence of the disease and the risk factors in transmission remains limited after 50 years (Kemming et al., 2004). In addition, studies examining Candidatus mycoplasma haematoparvum and Mycoplacma haemocanis infection have not been came across in this country except for one study (Foley et al., 2001).Therefore, this study was planned to investigate prevalence of Candidatus mycoplasma haematoparvum and Mycoplacma haemocanis infection in dogs.

\section{MATERIAL AND METHODS}

Study population consisted of 294 dogs (140 females, 154 males). To determine molecular and haematological parameters, $2 \mathrm{ml}$ blood with and without anticoagulant were taken according to technique from $\mathrm{V}$. cephalica. The dogs were clinically examined and blood samples with and without anticoagulant were drawn into tubes for haematological and molecular analysis. Prepared blood smears were stained with Geimsa method and examined under light microscope according to the literature (Foley et al., 2001).

Blood was processed for DNA extraction as described by d'Oliveira et al. (1995). Briefly, 200: L of thawed blood was washed 3-5 times by mixing with $0.5 \mathrm{~mL}$ PBS (137mM NaCl, $2.6 \mathrm{mM} \mathrm{KCl,} \mathrm{8.1mM} \mathrm{Na2HP04,} 1.5 \mathrm{mM}$ $\mathrm{KH} 2 \mathrm{P0} 4, \mathrm{pH}$ 7.4), each time followed by centrifugation at maximum speed $(13,000 \mathrm{rpm})$ for $5 \mathrm{~min}$. After the final wash, the cell pellet was resuspended in 100: $\mathrm{L}$ of lysis mixture (10mM Tris- $\mathrm{HCl}, \mathrm{pH} 8.0,50 \mathrm{mM} \mathrm{KCl,} \mathrm{0.5 \%}$ Tween 20, and 100: $\mathrm{g} / \mathrm{mL}$ of proteinase $\mathrm{K}$ ). This mixture was incubated overnight at $56^{\circ} \mathrm{C}$, followed by $10 \mathrm{~min}$ of boiling to inactivate the Proteinase $\mathrm{K}$ and kept at $-20^{\circ} \mathrm{C}$ until needed for PCR for amplification of the 16S rRNA gene (Dean et al., 2008).

The DNA samples from cattle blood were used in PCR reactions (Reverse line blot-PCR) to amplify any Anaplasma (or even any Ehrlichia) 16S rRNA gene present. One primer set was used to amplify a 309-328 bp fragment being part of the $\mathrm{V} 1$ region of the $16 \mathrm{~S}$ rRNA gene. The forward primer was (EF416566) (5'-GAAACTAAGGCCATAAATGACGC -3') for Mycoplacma haemocanis and (HQ918288) (5'-ACGAAAGTCTGATGGAGCAATAC-3') for Candidatus mycoplasma haematoparvum whereas the reverse primer was (5'- ACCTGTCACCTCGATAACCTCTAC-3') for Mycoplacma haemocanis and (5'-TATCTACGCATTCCACCGCTAC-3') for Candidatus mycoplasma haematoparvum. The $1 \mathrm{xPCR}$ reaction constituents in a final volume of 25: L were as follows: 1xPCR buffer (Invitrogen), $3.0 \mathrm{mM} \mathrm{MgCl} 2$ (Invitrogen), 200: $M$ each dATP, dCTP, dGTP, 100: M dTTP (ABgene) and 100: M dUTP (Amersham), 1.25 U of Taq polymerase (Invitrogen), 0.1U of UDG (Amersham), 25 pmol of each primer and 2.5: L of template DN A. This was over laid with about 12.5: L of mineral oil. Positive control DNA (E. canis) from Molecular Biology Laboratory, Makerere University and negative control (reaction constituents without DNA) tests were included. The reactions were performed using a three phase touchdown program as previously described (Barker et al., 2009; Brinson et al., 2001). The possible presence of ectoparasites on the dogs was also looked for carefully. Statistical analyses were done using SPSS for Windows.

\section{RESULTS AND DISCUSSION}

Clinical signs including temperature, pulsation and respiration rates were in normal ranges. Some of the infected cats had anorexia and weight loss. Microscopic examination revealed Candidatus mycoplasma haematoparvum and Mycoplacma haemocanis in 26 (8.82\%) cats. The animals had no ectoparasites on them. Baseline haematological and biochemical findings did not differ after the treatment. Appearance of Candidatus mycoplasma haematoparvum and Mycoplacma haemocanis in Geimsa staining of blood smears is presented. According to the results sex had no effect on the infection of the dogs (P > 0.05) (Tables1, 2 and 3).

In this study, we used histological methods and novel molecular techniques to determine the regional prevalence and identity of Candidatus mycoplasma haematoparvum and Mycoplacma haemocanis. Of 294 samples, 66 supported amplification of parasite rRNA by PCR. 25 samples were then examined in parallel by microscopic 


\begin{tabular}{|c|c|c|c|}
\hline Sex & Number & Positive & $\%$ \\
\hline Female & 140 & 12 & 8.57 \\
\hline Male & 154 & 17 & 11.03 \\
\hline Total & 294 & 29 & 9.86 \\
\hline
\end{tabular}

\begin{tabular}{|c|c|c|c|}
\hline Sex & Number & Positive & $\%$ \\
\hline Female & 140 & 15 & 10.71 \\
\hline Male & \begin{tabular}{|l|l|}
154 \\
\end{tabular} & $\begin{array}{ll}18 \\
\end{array}$ & 11.68 \\
\hline Total & 294 & 33 & 11.22 \\
\hline
\end{tabular}

Table 3. Distributions of the findings according to the sex of the cats Mycoplacma haemocanis and Candidatus mycoplasma haematoparvum by pcr

\begin{tabular}{|l|l|l|l|}
\hline Sex & Number & Positive & $\%$ \\
\hline Female & 140 & 26 & 18.57 \\
\hline Male & 154 & 33 & 21.42 \\
\hline Total & 294 & 59 & 20.06 \\
\hline
\end{tabular}

examination and PCR. One samples positive by initial microscopic examination were not amplified by PCR. Thirty-nine PCR-positive samples did not contain sarcocysts on initial microscopic examination, but additional sections from these samples revealed sarcocysts in an additional 12 samples. The partial sequence analysis of the16S rRNA gene (both sequences had $150 \mathrm{bp}$ ) indicated a homology of 100\% between the PCR amplicons of the positive samples and Candidatus Mycoplasma haematoparvum.

The infection was most probably transmitted by ectoparasites (Wood et al., 2006). In conclusion, a rate of haemobartonellosis of $22.45 \%$ was determined in dogs and it is believed that haemobartonellosis should always be suspected in dogs presented to veterinary clinics with non-specific symptoms. In addition, serological investigations should also be done in future studies to document the prevalence of the disease in this country.

Polymerase chain reaction (PCR) has been increasingly applied to detect these pathogens in both blood and tick vectors instead of microscopy. Although a number of publications report the use of PCR, most publications are based on 6 original methods for all pathogens (Roura et al.,2005; Sykes et al., 2005; Bauer et al., 2008; Sasaki et al., 2008;). Many reports summarised compare PCR detection with serology to demonstrate assay specificity. However, the most suitable detection method depends upon whether antigen or antibody detection is relevant for the particular investigation, detection of parasites, or current infection, prevalence studies or evidence of exposure to parasites.

Although PCR is more sensitive than light microscopy (Kemming et al., 2004), this method complicated postPCR detection methods to further enhance the sensitivity and confirm the specificity of the PCR technique such as PCR-ELISA and PCR-probe hybridisation. A quantifiable PCR technique referred to as real time PCR (also known as 5' Taq nuclease assays, fluorogenic probe assays, or TaqMan_assays), are increasingly applied for the detection and identification of animal pathogens and do not require post PCR electrophoresis or processing steps (Gentilini et al.,2009).

Real time assays exploit the 5' nuclease activity of Taq DNA polymerase cleaving a dual labelled fluorescent probe which has annealed to a specific sequence between two primers (Francino et al., 2006; Peters et al., 2008; Wengi et al., 2008). To date, the applications of real time PCR for the detection of tick borne disease pathogens have been described for Theileria spp. and Anaplasma spp. (Taber et al.,2009; Lako et al., 2010). It may not be feasible for certain laboratories to use PCRELISA, PCR-probe hybridisation or real time PCR assays as the application of each of these methods requires specific and expensive reagents and equipment. Microscopy remains the most economic and sustainable method of parasite detection for all laboratories.

This is the first case of canine infection with Candidatus Mycoplasma haematoparvum in Iran. This organism, named Candidatus Mycoplasma haematoparvum is smaller (0.3 _ $\mathrm{m}$ in diameter) and does not form chains on the erythrocyte surface of dogs (Sykes et al., 2005). The infection has been confirmed by methods of molecular biology (Jensen et al., 2001). In France, a 15.4\% prevalence of haemoplasma infection in dogs, as well as the presence of coinfection of both haemoplasmas, has been registered using the PCR test (Kenny et al., 2004).

Further researches on haemotropic mycoplasmas are indispensable, regarding that: haemoplasmas might act as cofactors in the progression of retroviral, neoplastic and immunologically mediated diseases; the factors of the virulence and pathogenic mechanisms in the development of these infections, as well as the functions of the immunologic system, which is in this case again responsible for the occurrence of new opportunistic infections, are not known (Messick, 2004). Until now, there is no evidence that canine haemoplasmas cause human diseases, but regarding the fact that feline and swine haemotropic mycoplasmas have zoonotic potential, future researches should be conducted in this direction (Xavier Roura et al., 2010; Wu et al., 2006).

The hemoplasma sample prevalence was significantly higher in Switzerland (8.7\%) than in Spain (2.5\%) (Willi 
et al.,2006; Lako et al., 2010; Xavier et al., 2010). Risk factors for infection included living in kennels, young age, crossbreeding, and mange infection. Among the PCR-positive dogs, 40\% were infested with blood-sucking arthropods. No association was found with anemia.

\section{ACKNOWLEDGEMENTS}

We thank Hamid Reza Arshad Riahi and Manochehr Momeni for their enthusiastic support of this work.

\section{FINANCIAL SUPPORT AND SPONSORSHIP}

Nil.

\section{CONFLICT OF INTEREST}

There are no conflicts of interest.

\section{RREFRENCES}

Barker E.N., S. Tasker, M. Day, S.M. Warman, K. Woolley, R. Birtles, K.C. Georges, C.D. Ezeokoli, A. Newaj-Fyzul, M.D. Campbell, O.A.E. Sparagano, S. Cleaveland and C.R. Helps. (2009) Development and use of real-time PCR to detect and quantify Mycoplasma haemocanis and 'Candidatus Mycoplasma haematoparvum in dogs. Veterinary Microbiology Vol. 140: Pages 167-170.

Bauer N., H.J. Balzer, S. Thure and A. Moritz. (2008) Prevalence of feline hemotropic mycoplasmas in convenience samples of cats in Germany. Journal of Feline Medicine and Surgery Vol. 10: Pages 252-258.

Brinson J. J. and J. B. Messick., (2001) Use of a polymerase chain reaction assay for detection of Haemobartonella canis in a dog. Journal of the American Veterinary Medical Association Vol. 218: Pages 1943-1945.

Dean R.S., C.R. Helps, T.J. Gruffydd Jones and S. Tasker. (2008) Use of real-time PCR to detect Mycoplasma haemofelis and Candidatus Mycoplasma haemominutum in the saliva and salivary glands of haemoplasma-infected cats. Journal of Feline Medicine and Surgery Vol. 10: Pages 413-417.

Foley J. E. and N. C Pedersen. (2001) Candidatus Mycoplasma haemominutum, a low-virulence epierythrocytic parasite of cats. International Journal of Systematic and Evolutionary Microbiology Vol. 51: Pages 815-817.

Francino 0., L. Altet, E. Sanchez-Robert, A. Rodriguez, L. Solano-Gallego, J. Alberola, L. Ferrer, A. Sánchez and X. Roura. (2006) Advantages of real-time PCR assay for diagnosis and monitoring of canine leishmaniosis. Veterinary Parasitology Vol. 137: Pages 214-221.

Gentilini F., M. Novacco, M.E. Turba, B. Willi, M.L. Bacci and R. Hofmann-Lehmann. (2009) Use of combined conventional and real-time PCR to determine the epidemiology of feline haemoplasma infections in northern Italy. Journal of Feline Medicine and Surgery Vol. 11: Pages 277-285.
Jensen W.A., M.R. Lappin, S. Kamkar and W.J. Reagan. (2001) Use of a polymerase chain reaction assay to detect and differentiate two strains of Haemobartonella felis in naturally infected cats. American Journal of Veterinary Research Vol. 62: Pages 604-8.

Kemming G.I., J.B. Messick, G. Enders, M. Boros, B. Lorenz, S. Muenzing, H. Kisch-Wedel, W. Mueller, A. Hahmann-Mueller, K. Messmer and E. Thein. (2004) Mycoplasma haemocanis infection-a kennel disease. Comparative Medicine Vol. 54: Pages 404-409.

Kenny M.J., S.E. Shaw, F. Beugnet and S. Tasker. (2004) Demonstration of two distinct haemotropic mycoplasmas in French dogs. Journal of Clinical Microbiology Vol. 42: Pages 53975399.

Lako B., A. Potkonjak, J. Balzer, A. Grozdana, D. Radsolava, B. Topalski, M. Stevanevi and 0. Stevanevi. (2010) First report about canine infections with Candidatus mycoplasma haematoparvoum in Serbia. Acta Veterinaria (Beograd) Vol. 60, 5-6: Pages 507-512.

Lumb W.V. (2001) More information on haemobartonellosis in dogs. Journal of the American Veterinary Medical Association Vol. 219: Pages 732-733.

Messick J.B. (2004) Hemotrophic mycoplasmas (hemoplasmas): a review and new insights into pathogenic potential. Veterinary Clinical Pathology Vol. 33: Pages 2-13.

Murray R.G.E. and E. Stackebrandt. (1995) Taxonomic note: implementation of the provisional status Candidatus for incompletelydescribed procaryotes. International Journal of Systematic Bacteriology Vol. 45: Pages 186-187.

Neimark H., J.K.E Ohansson, Y. Rikihisa and J.G. Tully. (2001) Proposal to transfer some members of the genera Haemobartonella and Eperythrozoon to the genus Mycoplasma with descriptions of 'Candidatus Mycoplasma haemofelis', 'Candidatus Mycoplasma haemomuris', 'Candidatus Mycoplasma haemosuis' and 'Candidatus Mycoplasma wenyonii'. International Journal of Systematic and Evolutionary Microbiology Vol. 51: Pages 891-899.

Neimark H., K.E. Johansson, Y. Rikihisa and J.G. Tully. (2002) Revision of haemotrophic Mycoplasma species names. International Journal of Systematic and Evolutionary Microbiology Vol. 52: Pages 683.

North D. C. (1978) Fatal haemobartonellosis in a non-splenectomized dog - a case report. Journal of Small Animal Practice Vol. 19: Pages 769-773.

Peters I.R., C.R. Helps, B. Willi, R. Hofmann-Lehmann and S. Tasker. (2008) The prevalence of three species of feline haemoplasmas in samples submitted to a diagnostics service as determined by three novel real-time duplex PCR assays. Veterinary Microbiology Vol. 126: Pages 142-150.

Pitulle C., D. M.Citron, B. Bochner, R. Barbers and M. D. Appleman. (1999) Novel bacterium isolated from a lung transplant patient with cystic fibrosis. Journal of Clinical Microbiology Vol. 37: Pages 3851-3855.

Roura X., E. Breitschwerdt, A. Lloret, L. Ferrer and B. Hegarty. (2005) Serological evidence of exposure to Rickettsia, 
Bartonella and Ehrlichia spp. in healthy or Leishmania infantum infected dogs from Barcelona. The International Journal of Applied Research in Veterinary Medicine Vol. 3: Pages 129138.

Roura X., I.R. Peters, L. Altet, M.D. Tabar, E. N. Barker, M. lanellas, C. R. Helps, O. Francino, S. E. Shaw and S. Tasker. (2010) Prevalence of hemotropic mycoplasmas in healthy and unhealthy cats and dogs in Spain. Journal of Veterinary Diagnostic Investigation Vol. 22: Pages 270-274.

Sasaki M., K. Ohta, A. Matsuu, H. Hirata, H. Ikadai and T. Oyamada. (2008) A molecular survey of Mycoplasma haemocanis in dogs and foxes in Aomori Prefecture, Japan. Journal of Protozoology Research Vol. 18: Pages 57-60.

Seneviratna P., N. Weerasinghe and S. Ariyadasa. (1973) Transmission of Haemobartonella canis by the dog tick, Rhipicephalus sanguineus. Research in Veterinary Science Vol. 14: Pages 112-114.

Sykes J.E., N.L. Bailiff, L.M. Ball, O. Foreman, J.W. George and M.M. Fry. (2004) Identification of a novel haemotropic mycoplasma in a splenectomized dog with hemic neoplasia. Journal of the American Veterinary Medical Association Vol. 224: Pages 1946-1951.

Sykes J.E., L.M. Ball, N.L. Bailiff and M.M. Fry. (2005) Candidatus Mycoplasma haematoparvum, a novel small haemotropic mycoplasma from a dog. International Journal of Systematic and Evolutionary Microbiology Vol. 55: Pages 27-30.

Sykes J.E., J.C. Terry, L.L. Lindsay and S.D. Owens. (2008) Prevalences of various haemoplasma species among cats in the United States with possible hemoplasmosis. Journal of the American Veterinary Medical Association Vol. 232: Pages 372-379.

Splitter E. J., E. R. Castro and W. L. Kanawyer. (1956) Feline infectious anemia. Veterinary medicine Vol. 51: Pages 17-22.

Tabar M.D., O. Francino, L. Altet, A. Sánchez, L. Ferrer and X. Roura. (2009) PCR survey of vectorborne pathogens in dogs living in and around Barcelona,an area endemic for leishmaniosis, Veterinary Record Vol. 164: Pages 112-116.

Tasker S., C. R. Helps, M. J. Day, D. A. Harbour, S. E. Shaw, S. Harrus, G. Baneth, R. G. Lobetti, R. Malik, J. P. Beaufils, C. R. Belford and T. J. Gruffydd-Jones. (2003) Phylogenetic analysis of haemoplasma species - an international study. Journal of Clinical Microbiology Vol. 41: Pages 38773880.

Torkan, S., S. Nargesi and F. Khamesipour. (2014) The Comparative Study of the Treatment by Oxytetracycline and Homeopathy on Induced Mycoplasma Haemofelis in Less than OneYear-0ld Cats. International Journal of Animal and Veterinary Advances Vol. 6: Pages 97-102.

Wengi N., B. Willi, F.S. Boretti, V. Cattori, B. Riond, M.L. Meli, C.E. Reusch, H. Lutz and R. Hofmann-Lehmann. (2008) Real-time PCR-based prevalence study, infection followup and molecular characterization of canine hemotropic mycoplasmas. Veterinary Microbiology Vol. 126: Pages 132-41.

Willi B., S. Tasker, F.S. Boretti, M. G. Doherr, V. Cattori, M. L. Meli, R. G. Lobetti, R. Malik, C. E. Reusch, H. Lutz and R. Hofmann-Lehmann. (2006) Phylogenetic analysis of "Candidatus Mycoplasma turicensis" isolates from pet cats in the United Kingdom, Australia, and South Africa, with analysis of risk factors for infection. Journal of Clinical Microbiology Vol. 44: Pages 4430-4435.

Woods J.E., M.M. Brewer, J.R. Hawley, N. Wisnewski and M. R. Lappin. (2006) Evaluation of experimental transmission of 'Candidatus Mycoplasma haemominutum' and Mycoplasma haemofelis by Ctenocephalides felis to cats. American Journal of Veterinary Research Vol. 66: Pages 1008-1012.

Wu J., J. Yu, C. Song, S. Sun and Z. Wang. (2006) Porcine eperythrozoonosis in China. Annals of the New York Academy of Sciences Vol. 1081: Pages 280-5. 